\title{
Student Scientific Publication at The Department of International Relations, UPN 'Veteran' Yogyakarta: An Action Research
}

\author{
Iva Rachmawati* \\ Erna Kurniawati \\ Melaty Anggraini \\ International Relation Department, \\ Faculty of Social and Political Sciences, \\ Universitas Pembangunan Nasional 'Veteran' Yogyakarta, Indonesia \\ ${ }^{*}$ Corresponding Author
}

DOI: https://doi.org/10.36941/jesr-2021-0133

\begin{abstract}
This study aims to find the right strategy for increasing scientific publications for students of the Department of International Relations, UPN 'Veteran' Yogyakarta, Indonesia. Thus, it is essential to consider the low number of scientific publications produced by students considering that scientific publications are an obligation for academics. The Director-General of Higher Education Letter No. 152/E/T/2012 concerning the duty of scientific publications for students and Regulation of the National Accreditation Board for Higher Education Number 5 of 2019 concerning Study Program Accreditation Instruments requires publication and citation student scientific articles. The research uses action research to find strategies for increasing scientific publications where there are three research steps: identifying problems, making and testing procedures, and evaluating. The second step is to try the strategy based on problem identification. Problem identification is made through an online open questionnaire. The third step is the evaluation of the action research. Experiments conducted to influence student behavior in scientific writing showed that socialization and coaching clinics were needed to increase knowledge about scientific writing and encourage ideas. While writing assistance can produce student scientific publications because of its nature and able to foster comfort. This empirical evidence provides insights for the manager of student scientific journals and department managers to provide formulations for improving students' quality and quantity of scientific publications.
\end{abstract}

Keywords: Scientific Publication, Action Research, Scientific Journal, Writing Assistance

\section{Introduction}

Scientific publications are evidence of scientific accountability for research results to be widely known globally (Widyanuratikah and Putra. 2019). The state's issuing the Director-General of Higher Education Letter No. 152/E/T/2012 regarding the obligation of scientific publications for undergraduate, postgraduate, and doctoral students to improve scientific publications. The circular stated several provisions: a) Requirements to pass the $\mathrm{S} 1$ or Bachelor program must produce scientific 
articles published in scientific journals. b) The requirements for passing the Masters or Doctoral program must have produced scientific articles published in national scientific journals and accredited by the Higher Education. c) The requirements for passing the postgraduate or doctoral program must have produced scientific articles. They have to publish their scientific paper in international scientific journals before finish the program. However, the Director-General of Higher Education Letter No. 152/E/T/2012 has not increased the number of student scientific articles. In general, according to data released by ISJD or Indonesia Scientific Journal DataBase in 2014-2020, there was a decrease in the number of articles published in Indonesian journals from 50,000 articles, down to only 15,679 in 2020 (ISJD, http://isjd.pdii.lipi.go.id/).

In 2019, the Ministry of Research, Technology and Higher Education issued Regulation of the National Accreditation Board for Higher Education Number 5 of 2019. The regulation deals with Study Program Accreditation Instruments. One of the demands of the APS 4.0 is to increase the publication of student-owned scientific papers and citations of student-owned scientific works. Of course, this demand is not easy to fulfill, considering very few student journals. In Indonesia, there are only 28 registered student journals (ISJD. http://isjd.pdii.lipi.go.id/index.php/public_no_login/ index_direktori\#). These journals are managed by student associations, student research institutes, the Student Executive Board, and others in part. This number is, of course, not comparable to the number of universities and even majors throughout Indonesia.

In the Department of International Relations, Universitas Pembangunan Nasional 'Veteran' Yogyakarta (UPN 'Veteran' Yogyakarta), students do not yet have a scientific journal. Students who do scientific publications are only those who have completed their thesis. These students publish their research results in the Diplomacy and Security Studies Journal (JSDK) issued by the Department of International Relations, UPN 'Veteran' Yogyakarta, and Paradigm Journal published by the Faculty of Social and Political Sciences, Universitas Pembangunan Nasional "Veterans "Yogyakarta. The number of students who post their thesis in those two journals is still very least. Since 2018, there have only been five student thesis articles that have been successfully published through the JSDK (Journal of Diplomacy and Security Studies, http://jurnal.upnyk.ac.id/index.php/jsdk). The Department of International Relations has only published three articles since 2018 (Paradigm, http://jurnal.upnyk.ac.id/index.php/paradigma).

On the other hand, many students try to publish their scientific articles through non-reviewed pages such as Academia.edu, Research. Gate and personal blogs or using social media such as LinkedIn. For example, Dilla Rinda Pratiwi's papers can be found on the https://independent.academia.edu/ page, titled "Background on the Postponement of Israel's West Bank Annexation Plan." On the https://independent.academia.edu/page, you can also find the writings of Al Faiz Alif Yudhistira with the title "Toxic Masculinity in Contemporary Globalization: A Case Study of Toxic Masculinity in Indonesia" and Rania Nabilla's essays with the title "Second Libyan Civil War and its Great Influence. Foreign Intervention", "Indonesian Foreign Policy in the Resolution of the Vietnam-Cambodia Conflict in 1970-1991", and "The Issue of Propaganda and Identity Politics in Machiavelli's View." At the same time, Dhayan Wijaya posts his writing using his blog https://dhayanwijaya.wordpress.com/. Of course, we have to appreciate those works, but scientific results need a review process to reference other research. Thus, the student's scientific works have not fulfilled the APS. 4.0 demands.

Several studies have found that increasing student scientific publications can be encouraged by organizing a forum for scientific publications (Sugilar et al., 2019) and coaching clinics (Ismail and Elihami, 2019; Supriyanto et al., 2015). A coaching clinic can be a strategic encouragement where students get help with an individual approach to compiling their scientific articles. Meanwhile, Rahil Mahyuddin et al. (2006) stated, "Effective assistance allows students to believe that they can carry out writing tasks, but less assistance from the teacher will decrease the learners' confidence." Writing assistance can be a beneficial strategy also in scientific publications because it can increase student confidence. Confidence in writing is the principal capital for a writer to present the results of his thoughts to the public. When the learners have high self-efficacy, they will feel competent and 
confident, and they are more willing to persevere when confronting obstacles (Pajares \& Valiante, 2008). Self-efficacy is a "cognitive construct that represents individuals' beliefs and personal judgments about their ability to perform at a certain level and affects the choice of activities, effort, and performance" (Hidi \& Boscolo, 2008:148). When an individual recognizes self-efficacy, it enables him to set goals, achieve them; it boosts determination and revival from dissatisfaction and malfunctioning. It can be observed as a constructive viewpoint or practical technique to deal with the complications (Ahmed et al., 2011). Self-efficacy can also overcome writing disabilities. According to Stein, Dixon, and Isaacson (1994), it may derive from too little time allocated to writing instruction or from writing instruction inadequately designed around the learning needs of many students. Trioa (2003) suggests that the problems experienced by students in writing are attributable, in part, to their difficulties in executing and regulating the processes which underlie proficient composing, planning, and revisions of their work.

The research aims to find the right strategy for increasing scientific publications by students of the Department of International Relations UPN 'Veteran' Yogyakarta, referring to the problems faced by students. The research uses action research to find the right strategy in increasing student scientific publications. Instead of identifying problems, this research can also test systems and produce appropriate strategies according to the issues students face of the Department of International Relations, UPN 'Veteran' Yogyakarta.

\section{Method}

\section{$2.1 \quad$ Research Design}

Action research is collaborative self-reflective research conducted by participants in social sciences and education to improve their understanding and implementation of their work, and also to have an impact on the surrounding environment in line with what was conveyed by Burns (2015), that Action Research has the aim of ( a) bring about positive change and improvement in the social situation of the participants; (b) generate theoretical as well as practical knowledge of the situation; (c) increase collegiality, collaboration, and involvement of participants who are actors in situations and are likely to occur and (d) build attitudes for change, self-development, and sustainable growth. This idea is the same as that conveyed by Kartowagiran (1998). Action Research is research carried out collaboratively by social sciences and education participants to improve understanding and implementation of their work and impact the surrounding environment. In this case, Action Research can be used in education, both inside and outside the classroom. Johnson (2012) asserts that action research bridges the gap between research and practice. For instance, the theoretical components underpinning action research understand and observe what happens in a classroom setting. At the same time, and with the interests of the best course in mind, these collected data "are used to understand or inform theories and research related to best practice."

According to Kartowagiran (2005), the elements of Action Research are 1. improving their work, 2. collaborating with other people or groups to improve their work, and 3. collaborating with other agencies separately to create projects or develop new systems. Meanwhile, according to Lodico et al. (2006: 290-291), Action Research has the following characteristics: (a) It is carried out in the educational environment of the researchers themselves, and practitioners take an active part in the research. It also ensures that research is grounded in the realities of everyday educational practice. (b) Action research involves collaboration with other educators and people involved in the educational process. However, mutual respect for the expertise that everyone brings to the process is the main character of the action research. (c) Focus on the effort to change and improve educational practice. (d) It takes place and includes several waves of data collection, reflection, and action.

The Action Research process begins with identifying the problem and formulating possible actions to overcome the problem and evaluate the action results. Action Research is fluid and flexible, so it is necessary to prescribe more than a set sequence of steps to follow. In contrast to research 
approaches that follow more predictable and established procedures. According to Burns (2015), Action Research is characterized by dynamic movement, flexibility, exchange, and repetition throughout the study; thus, a researcher must prepare for variation and repetition in conducting Action Research. Unexpected in the process. The following is the action research process regarding efforts to increase scientific publications for students of the Department of International Relations at the National Development University 'Veteran' Yogyakarta.

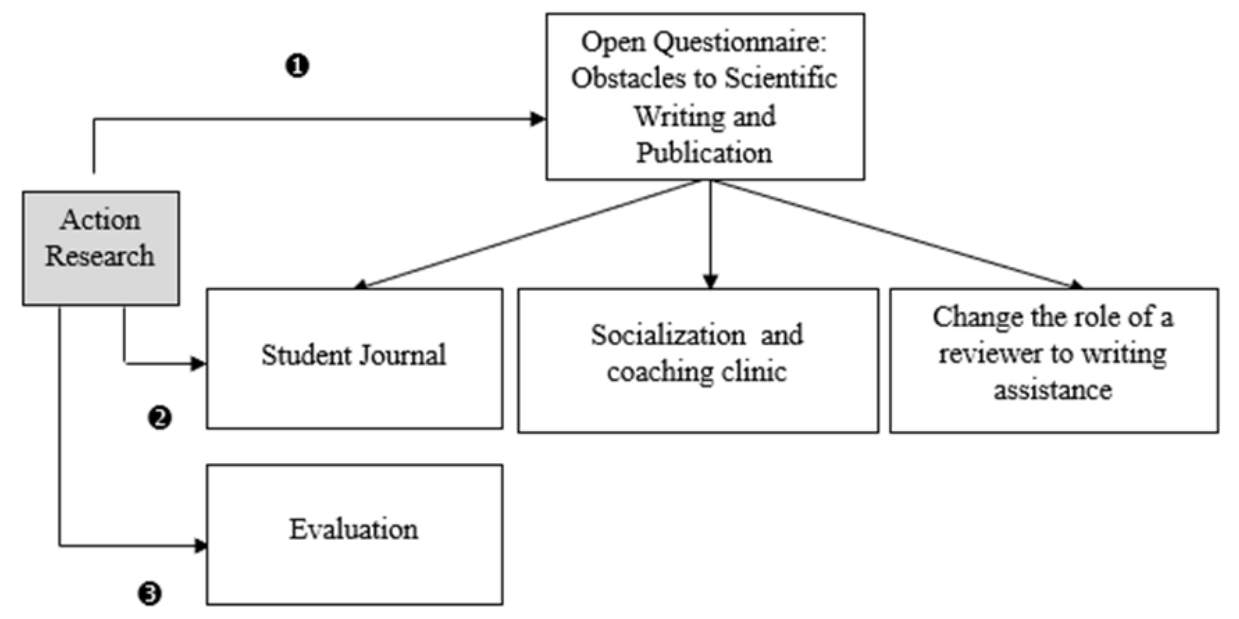

\section{Chart 1: Action Research Steps}

The first stage - problem identification - samples taken from 306 students of the Department of International Relations, Faculty of Social and Political Sciences, UPN 'Veteran' Yogyakarta class 20182020. The second stage, testing the socialization strategy and coaching clinic, took the sample from 200 students. At the same time, the writing assistance strategy test was carried out on 11 students $(7$ articles).

\subsection{Research Instrument and Procedures}

To identify the problem, the researchers used an open questionnaire. According to Riduwan (2014: 99-100), a questionnaire (questionnaire) is a list of questions given to other people who are willing to respond (respondents) according to user requests. There are two types of questionnaires, namely: open questionnaires and closed questionnaires. An open questionnaire (unstructured questionnaire) is a question set presented in a simple form so that respondents can provide information according to their wishes and circumstances. Meanwhile, a closed questionnaire (structured questionnaire) is a questionnaire that is a question set presented in such a way that the respondent can only choose one answer that fits their characteristics, employing a cross $(\mathrm{x})$ or a checklist $(\sqrt{ })$. This research using an open questionnaire consists of ten questions regarding scientific writing and publications. Because Pandemic Covid 19 limited the face-to-face meeting, the study conducted the available online questionnaire to gather the information needed. The answers from 306 students as a sampling of + 730 students will be reclassified in 'never had a problem,' 'rarely had a problem,' and 'often had a problem.' To make it easier to find the most answers to determine strategies. The second step is to develop a strategy related to the obstacles found. The three strategies to be tested are: create an OJS/Online Journal System, conduct socialization and coaching clinic, and changes the role of reviewers as writing assistance. OJS and socialization are carried out simultaneously to encourage 
students' scientific writing and introduce them to the OJS system. A coaching clinic also followed this socialization for students to prepare manuscripts and the writing assistance.

Changing the role of blind peer review in journals into writing assistance aims to change the task of assessing and criticizing writing into a scheme to help students improve their writing so that the paper is worthy of publication. The Peer Review Process is when journals evaluate the quality of manuscripts before publication and review by relevant experts in their fields to review and comment on accepted manuscripts. This process aims to help editors determine whether manuscripts should be published in a journal. In contrast to peer-reviewing student writing in teaching, this practice shows that peer review is intended to reduce the instructor/teacher's workload related to writing activities (Cho and Schunn, 2005). Peer reviewing can help students in increasing the quality of the writer's work. This action research will replace the blind review system with writing assistance. So that all submitted writings have the opportunity to improve their quality so that they can be published, not just criticized and judged to be worthy or not worthy of publication. The entire trial will be evaluated, referring to the results obtained from each stage. The results of the evaluation will show strategies that make a positive contribution to increasing student scientific publications.

\subsection{Data Analysis}

The data analysis technique used is qualitative descriptive analysis. Qualitative descriptive efforts are that of a composite sketch artist. The underlying idea is that this artist has the role of depicting a 'reality.' based on the reports of the witnesses. In other words, the artist has a duty of drawing a picture according to the witnesses' memories, rather than substituting their speculation. The artist inevitably has their images in mind. Still, the aim is to capture the understanding of the other-a picture that the witnesses would agree represents the reality they experienced (Seixas et al. 2017). The purpose of this method is to get an accurate picture of reality. This is what Maxwell (19912) calls interpretive validity. Overall results from the online open questionnaire were classified in the never had problems category; rarely had problems; often had issues to make it easier for researchers to find the most difficulties in scientific publications. However, the respondents' answers will serve as a reference in this research and be interpreted. Interpretation of the interview is a consideration in determining the strategy as the core of action research. The results show the influence of each process taken so that this research can find the best method to encourage student scientific publications.

\section{Result}

This actions research consists of three stages. The first stage is to capture the obstacles faced by students through the survey method. This survey has 306 respondents who have to answer several questions about their knowledge and barriers in scientific writing and publication. This survey will help researchers understand respondents' perceptions of scientific journals and their understanding of scientific writing. The information obtained from the study will be the basis for determining the strategy. The surveys showed that $29 \%$ of respondents realized that scientific journals could improve their scientific writing skills; $27 \%$ of respondents said that scientific journals could help them increase their insight and knowledge, $19 \%$ of respondents stated that they could improve their quality. And their critical thinking power, and $7 \%$ of other students think that scientific journals can be a place for them to practice expressing their opinions through writing. Although only $19 \%$ of students realize the benefits of the articles they produce can increase their quality and increase the weight of their $\mathrm{CV}$, this can be a motivation for students to write and publish their writings. 


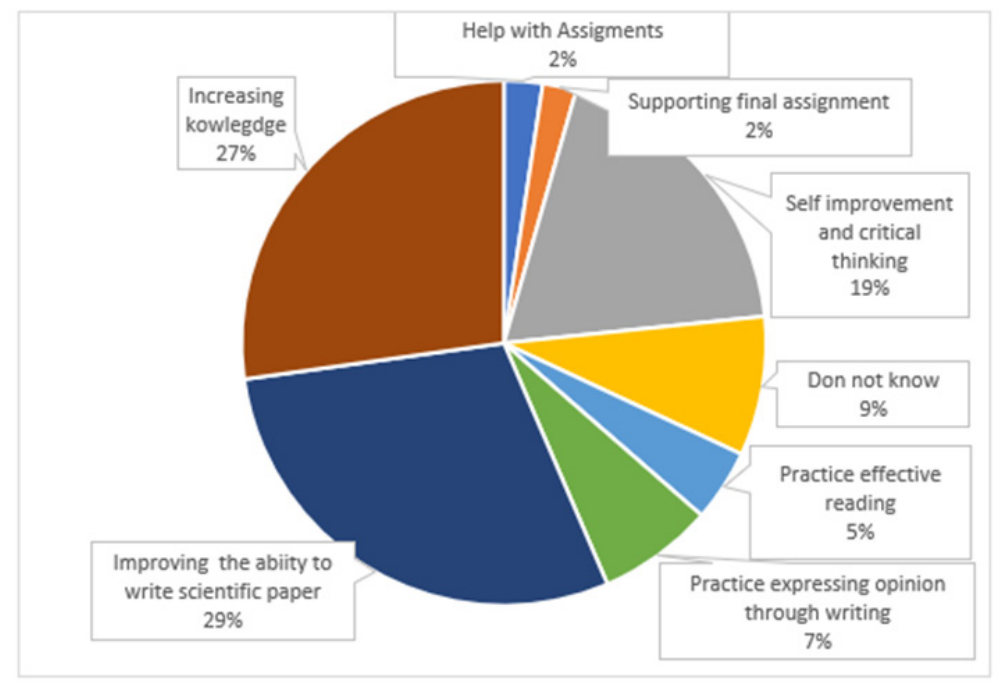

Diagram 1: Student Opinion on the Benefits of Scientific Journals

To make it easier for researchers to measure the obstacles faced by respondents, the researchers compiled a classification of constraints (never had problems; rarely had problems; often had issues). The answers' interpretation helps the researcher get a simple picture of the situation at hand, as shown in Table 1 below.

Table 1: Students' Barriers in Scientific Writing and Publication

\begin{tabular}{|c|c|c|c|c|}
\hline No. & Questions & $\begin{array}{l}\text { Never had } \\
\text { problems }\end{array}$ & $\begin{array}{l}\text { Rarely had } \\
\text { problems }\end{array}$ & $\begin{array}{l}\text { Often had } \\
\text { problems }\end{array}$ \\
\hline 1 & Having barriers to finding ideas & $1 \%$ & $23 \%$ & $76 \%$ \\
\hline 2 & Having problems in compiling writing systematically & $4 \%$ & $42 \%$ & $54 \%$ \\
\hline 3 & Having difficulty in using concepts/theories & $2 \%$ & $33 \%$ & $65 \%$ \\
\hline 4 & Having trouble finding and compiling data as arguments & $8 \%$ & $45 \%$ & $47 \%$ \\
\hline 5 & $\begin{array}{l}\text { Having problems in understanding the procedures for } \\
\text { scientific writing }\end{array}$ & $3 \%$ & $40 \%$ & $57 \%$ \\
\hline 6 & Having problems in making sentences and paragraphs & $10 \%$ & $57 \%$ & $33 \%$ \\
\hline 7 & $\begin{array}{l}\text { Having problems operating software to help with } \\
\text { writing (eg, Zotero/Mendeley) }\end{array}$ & $31 \%$ & $1 \%$ & $68 \%$ \\
\hline 8 & Having problems in providing research facilities and funds & $17 \%$ & $60 \%$ & $23 \%$ \\
\hline 9 & Having trouble understanding OJS & $12 \%$ & $59 \%$ & $29 \%$ \\
\hline 10 & $\begin{array}{l}\text { Having problems understanding the blind peer review } \\
\text { system system }\end{array}$ & $9 \%$ & $49 \%$ & $42 \%$ \\
\hline
\end{tabular}

The second stage of Action Research is to determine strategies to deal with the obstacles of scientific publications referring to the findings of the survey results. This research has already done three activities: conducting socialization and coaching clinics, building OJS, and writing assistance. Many lecturers disseminated scientific writing and publications through activities facilitated by students, but the results were not very effective. Throughout 2020-2021, socialization regarding scientific papers has been carried out four times by several lecturers using KSM (Kelompok Studi Mahasiswa / Student Study Group). From the socialization of scientific writing, there was no single draft of the manuscript produced by students. Students are still a passive group as objects of receiving material 
on a scientific paper and have not become active subjects as writers. However, this kind of socialization needs to be done regularly to increase students' knowledge about scientific writing.

Another activity carried out is encouraging students to produce writings through a literacy clinic organized by the Department of International Relations by inviting several scientific writing experts. The Literacy Clinic involved editors from IJIR-AIHII (Indonesian Journal of International Relations-Association of Indonesian International Relations Scientists), JSDK (Journal of Diplomacy and Security Studies), and students from the Department of International Relations at the 'Veteran' National Development University, Yogyakarta. The speaker in this activity was Susy Tekunan, Ph. D as the editorial editor of IJIR AIHII, who conveyed how to write a good scientific article. The other speaker were Dr. Iva Rachmawati as Chief Editor of JSDK National Development University 'Veteran' Yogyakarta, and Taufik, S. IP., MA, as Journal Manager of IJIR AIHII. The speaker presented material on how to publish papers in academic journals. Instead of discussion between speakers and participants, the participants attending writing training for five days (http://hi.upnyk.ac.id/berita/86/belajar-menulis-dan-publikasi-karya-tulis-ilmiah-dalam-acara\%E2\%80\%9Ccoaching-clinic\%E2\%80\%9D-klinik-literasi-lab-antar-budaya).

So far, scientific publications in journals are not an obligation for students in International Relations at the UPN 'Veteran' Yogyakarta. Students who have completed their thesis also have no obligation to publish their idea in a scientific article in a scientific journal. Requiring the publication of thesis results for students as full of graduation is a dilemma because scientific publications take a long time to go through peer review and revision of journal articles. However, on the other hand, this kind of obligation can increase.

The second strategy is to create a forum for students in scientific journals that have used OJS (Online Journal System). The Department of International Relations UPN, 'Veteran' Yogyakarta and students, work together to realize student scientific journals managed in the OJS system. This journal is intended only for students, and because it is only designed for students, it is students who coordinate the publicity process for scientific journals. Through a lengthy discussion, the researcher and the students finally produced the Pena Wimaya Journal, which launched on April 23, 2021. (http://hi.upnyk.ac.id/berita/117/jurusan-ilmu-hubungan-internasional-launching-jurnal-mahasiswa\%E2\%80\%9Cpena-wimaya\%E2\%80\%9D-untuk-mendorong-publikasi-ilmiah-mahasiswa-). The journal management team or Editors of the Pena Wimaya Journal are International Relations Students of UPN 'Veteran' Yogyakarta who have gone through the selection stage by the supervisor. The editorial team has specifically received training in online journal management and scientific writing to determine writing templates. We can find The Pena Wimaya website on the page http://jurnal.Universitas Pembangunan Nasional yk.ac.id/index.php/jpw.

The third strategy is assistance by changing the role of journal reviewers as writing assistance. In this effort, many student articles have been tested by considering ideas and scientific writing. After the refinement process, several writings are worthy of publication, namely:

i) Article "Diplomasi Masker China dan Keterlibatan People's Liberation Army" (China's Mask Diplomacy and the Engagement of the People's Liberation Army) by Muhammad Aditya Fairdiyanto, Mohammad Maulana Ilhami, and Dhiya Shifa Noor Hida.

ii) Article "Kudeta Militer: Junta Militer Era Modern" (Military Coup: Modern Military Junt ) by Fiki Rahmatina, Faustina Sari Dewi and Euneke Dewi Trihantari

iii) Article "Perlunnya Optimalisasi Tol Laut sebagai Sarana Penunjang Peningkatan Pembangunan Ekonomi Indonesia" (The Importance of Optimizing the Sea Toll Road as a Supporting Means of Increasing Indonesia's Economic Development) by Umi Salamah

iv) Article "Regionalisme dalam Regional Comprehensive Economic Partnership (RCEP): Sebuah Perspektif" (Regionalism in the Regional Comprehensive Economic Partnership (RCEP): A Perspective) by Muwaliha Syahdani.

v) Article "Analisis Aksi Lone Wolf Terorism : Penangkapan Abu Arkam Di Kabupaten Berau" (Analysis of Lone Wolf Terrorism Actions: Arrest Abu Arkam in Berau District) by Adrian and Melany Putry . 
vi) Article "Analisis Dukungan Vanuatu Terhadap Upaya Kemerdekaan Papua” (Analysis of Vanuatu's Support for Papua's Independence Efforts ) by Pratama Dinul Kusuma, Ganjar Widhiyoga and Andika Drajat Murdani.

vii) Article "Evaluasi Pengembangan Disaster Recovery Center untuk Data Center Universitas Udayana” (Evaluation of Disaster Recovery Center Development for Udayana University Data Center) by Muhammad Syaifudin.

Each of these articles received assistance from one lecturer, who acted as writing assistance. First, the reviewer will provide criticism and direction through the review facility found in OJS. However, the reviewer also allows students to ask questions and determine the best correction they can make. Students can make contact with reviewers for writing assistance. Fairdiyanto et al. had the opportunity to conduct several consultations via Zoom Meeting after obtaining writing notes through OJS. To improve the article, the student and reviewer had a lengthy discussion by considering the purpose of writing and the data possessed by the author. The initial weakness regarding China's mask diplomacy is that the paper has not shown the complexity of the problem regarding the urgency of China's mask diplomacy. Placing the issue's complexities is important to be understood by the author to make writing goals well and directed. The author needs to address the second thing that needs to adjust the concepts used with appropriate references. We can find these articles on the page http://jurnal.upnyk.ac.id/index.php/jpw/article/view/4702/3496.

The article entitled "Regionalism in the Regional Comprehensive Economic Partnership (RCEP): A Perspective" by Syahdani was rebuilt using Louise Fawcett's idea of regionalism as the reviewer's input. The concept of regionalism leads the author to explain better the development and contribution of the Regional Comprehensive Economic Partnership for its member countries. We can find the articles on the page http://jurnal.upnyk.ac.id/index.php/jpw/article/view/4807/3495.

Rahmatina et al., who wrote about democracy in Myanmar, received support to improve her writing systematics. The writing assistance received by Rahmatina et al. helped her to trace the stages of Myanmar's democratization process so that it was easier for readers to understand the recurring problems in Myanmar. This way of writing makes it easier for the author to see the frequent issues in Myanmar, which causes the democratic process to face challenges too often. Thus, the author can present the situation's complexity in a simple way for the reader, which is the researcher's task. We can find Rahmatina et al.'s article on the page http://jurnal.upnyk.ac.id/index.php/jpw/article/view/4637. Salamah's article on the urgency of optimizing the sea highway criticizes implementing the sea highway project in the Jokowi government. Even though the concept or theory is still weak, the writing assistance that supports Salamah can help her improve the urgency of writing which is the basis of each article. Scientific writing technical assistance is also beneficial for this paper to be published in the Pena Wimaya journal. Salamah also received help in finding and compiling data. Her assessment of the failure of the marine highway project has a reasonably good argument. We can see the article on the page http://jurnal.upnyk.ac.id/index.php/jpw/article/view/4649/3488 .

Meanwhile, Adrian and Melany Putry improved their writing regarding research urgency, data preparation, and references from the writing assistance. The writing speed needs to be emphasized, considering that a descriptive essay aims to describe a phenomenon. The urgency of the research will guide the author in compiling the data and selecting references. The data collected must describe terrorist behavior well so that readers get a good picture of lone-wolf terrorism. The article "Analysis of Lone Wolf Terrorism Actions: Arresting Abu Arkam in Berau Regency" can be a reference for readers to understand the types of terrorist behavior. We can find the article on the page http://jurnal.upnyk.ac.id/index.php/jpw/article/view/4636.

The other two articles belong to Kusuma et al. and Syaifudin. However, they have gone through writing assistance, and they have not been able to meet the deadline given by the editor. Determination of deadlines is given to authors and providing knowledge about the rules in scientific publications and providing direct experience to them so that they can work according to the deadlines given by the editor. These papers have some weaknesses, including the focus of not following the title, inappropriate concepts/theories, and data that have not supported 
arguments/explained the problem. Because both of them were unable to meet the deadline as suggested by the writing assistance, neither could be published by Pena Wimaya in July 2021.

\section{Discussion, Conclusion and Recommendations}

The online open questionnaire results show the positive perspective of the respondents about scientific writing. The survey finds out that respondents see the scientific writing can improve writing skills and increase self-confidence,

Melatih critical thinking, melatih ketrampilan menulis, melatih kemampuan menuangkan ide dalam tulisan ilmiah yang terstruktur (Train critical thinking, practice writing skills, practice the ability to express ideas in structured scientific writing) (Online Open Questionnaire, Sarwendah Puspitaningtyas, Juni 2021).

Manfaat menulis artikel ilmiah bagi mahasiswa yaitu antara lain: melatih pengembangan membaca secara efektif, melatih mahasiswa dalam mengorganisir fakta dan data, memperluas cakrawala ilmu pengetahuan mahasiswa dan masih banyak lagi (The benefits of writing scientific articles for students include training in effective reading development, training students in organizing facts and data, expanding students' knowledge horizons, and much more). (Online Open Questionnaire, Sella Agresia Br Sagala, Juni 2021)

Membantu berpikir secara sistematis serta membantu menguasai kompetensi tertentu terutama bidang yang diteliti dan menjadi sarana bagi mahasiswa untuk lebih kritis dalam menyampaikan ide (Helping to think systematically and helping to master certain competencies, especially the fields being researched, and becoming a means for students to be more critical in conveying ideas). (Online Open Questionnaire, Hastian Akbar Stiarso, Mei 2021).

The biggest obstacle faced by students in writing is finding ideas for writing ( $76 \%)$. Several students revealed that determining the topic of the paper was not an easy thing for them. In addition to doubting whether the theme is worthy of being adopted as research, they also experience difficulties presenting it in an interesting article. In some interviews, students stated,

Sulit dalam menemukan atau menentukan ide untuk menuliskannya dan juga kurangnya rasa percaya diri untuk menuangkan pikiran dalam karya tulis tersebut. (It is difficult to find or determine the idea to write it down and also lack the confidence to express thoughts in the written word). (Online Open Questionnaire, Gyorffi Jessica, Mei 2021)

Kendala terbesar saya yaitu dalam memulai atau membuat narasi dan gambaran awal dari tema yang saya bawakan, kadang saya sulit untuk konsisten terhadap topik yang saya tulis (My biggest obstacle is in starting or making a narrative and initial description of the theme that I bring; sometimes, I find it challenging to be consistent with the topics I write). (Online Open Questionnaire, Dewi Rayyan, April 2021)

Saya terkadang mengalami kendala berupa keraguan atau kebingungan mengenai topik apa yang akan saya gunakan serta mengalami kesulitan mencari referensi untuk topik -topik yang cenderung baru maupun topik-topik yang jarang diangkat atau topik yang tidak terlalu banyak menarik perhatian (I sometimes experience problems in the form of doubts or confusion about what topics I will use and have difficulty finding references for topics that tend to be new or topics that are rarely raised, or issues that do not attract too much attention). (Online Open Questionnaire, Ananda Vania Putri, April 2021)

In addition to experiencing problems with ideas in compiling scientific writings, students face difficulty formulating a systematic flow of thought (57\%). Several students stated that they actually experienced confusion and often stopped in the middle of writing.

Menyusun butir-butir opini dan menjadikannya satu kesatuan karya ilmiah yang layak untuk 
dipublikasikan (Arrange the points of opinion and make it a unified scientific work that deserves to be published). (Online Open Questionnaire, Arvisca Vandini PB, April 2021

Menyambungkan satu paragraf ke paragraf lain, mencari masalah dan latar belakang dari masalah tersebut, (Connecting one paragraph to another, looking for the problem and the background of the problem). (Online Open Questionnaire, Desak Putu Tirtha Nirmala Sarvasty, April 2021

Menyampaikan informasi dengan alur sistematis (Delivering information in a systematic flow ). (Online Open Questionnaire, Rafni Syahrani, Juni 2021)

Another difficulty that also overshadows students' writing is that some students do not quickly determine the concept or theory used in explaining the problem (65\%). Another thing that is also quite difficult for students is finding and compiling data to build arguments in line with the demands of the previously determined theory (47\%). Unfortunately, most students (68\%) do not understand and cannot operate software that can help scientific writing, such as Mendeley and Zotero, to help them develop scientific references.

Pencarian ide dan landasan teori yang cocok untuk artikel tersebut (Search for ideas and theoretical foundations that are suitable for the article). (Online Open Questionnaire, Yazid Ruziq Ibroham, Juni 2021)

Menentukan pisau analisis yang tepat untuk mengkaji fenomena (Determining the right analytical knife to study the phenomenon). (Online Open Questionnaire, Asy-Syifa R. Tyaswana, Juni 2021)

Menurut saya pribadi, kendala terbesar dalam menulis artikel ilmiah adalah mencari sumber referensi yang terkait topik penelitian yang sedang kita kerjakan. (In my personal opinion, the biggest obstacle in writing scientific articles is finding references that contain data or information related to our research topic). (Online Open Questionnaire, Oriza Sativa Ramadhana, Juni 2021)

Scientific writing should be something that students must master as the essential capital for them to write. However, surveys show that this is a significant obstacle faced by students. There are $57 \%$ of respondents do not understand the rules of scientific writing, and $33 \%$ of respondents have problems in making sentences and compiling paragraphs.

Kurang pemahaman akan penggunaan Footnote, Daftar Pustaka, Dan pembentukan Kalimat supaya tidak terkesan copy paste (Lack of understanding of the use of footnotes, bibliography, and sentence formation so as not to impress copy-paste). (Online Open Questionnaire, Mafhan Afriko, Juni 2021)

Saya mengalami kendala dalam memilihn kata yang tepat sehingga dapat menjelaskan apa yang di pikiran secara akurat (I'm having trouble choosing the right words so I can accurately explain what's on my mind). (Online Open Questionnaire, Anak Agung Bagus Dharma Guruh Mahendra, Mei 2021)

Mengefektifkan informasi dari data agar tepat sasaran dan tidak bertele tele sehingga penyampaian mudah dikonsumsi oleh pembaca (Streamlining information from data so that it is right on target and not long-winded so that readers quickly consume the delivery). (Online Open Questionnaire, Wenta Prasetya Ginting, April 2021).

Another obstacle in scientific writing which usually meet by students are they do not know about scientific publications or OJS (29\%) and the blind peer review system (42\%). Unfortunately, many journals often use to review scientific writings. The nescience happens because most students have never tried to submit their papers in scientific journals. Misunderstood student about scientific paper comes from the poor habit of writing a scientific essay and the unavailability of a forum for students at the Department of International Relations, UPN 'Veteran' Yogyakarta.

Unfortunately, the survey results show that many students still do not understand the procedures for scientific writing and even compile data as arguments. This obstacle may be a bit 
surprising. Students are an academic group who should understand how to write scientifically, search for data, process data and organize data to produce sound arguments. Doing research and reporting research results in writing is a student scientific activity that is carried out repeatedly. These facts become the basis for determining the following action research steps to influence the quantity and quality of student scientific publications.

Researchers applied three strategies to influence the quality and quantity of student scientific publications from the first stage results. These strategies are socialization and coaching clinic as well as writing assistance. From the first two strategies, the results showed that they were not optimal. Students who take part in the socialization and coaching clinic have not produced scientific publications. The lack of student scientific writing indicates that the new socialization and coaching clinic contributes to knowledge about scientific writing. However, the new socialization and coaching clinic has not encouraged students to produce scientific papers and publications.

Students still view that scientific writing is only related to the thesis, not to increase their writing quality and quantity. Awareness about the benefits of scientific publications for themselves is still relatively low. The online open questionnaire shows that only $19 \%$ of respondents stated that scientific work could improve their self-quality and critical thinking. And $29 \%$ of respondents said that scientific publications could improve writing skills.

Mengasah kemampuan analisa mahasiswa, sebagai publikasi penelitian yang bisa menjadi catatan tambahan untuk di CV mahasiswa (Sharpen students' analytical skills, as research publications that can be additional notes for students' CVs). (Online Open Questionnaire, Kunni Habibah Ilmi, May 2021).

Melatih critical thingking, melatih ketrampilan menulis, melatih kemampuan menuangkan ide dalam tulisan ilmiah yang terstruktur (Train critical thinking, practice writing skills, practice the ability to express ideas in structured scientific writing). (Online Open Questionnaire, Sarwedah Puspitaningtyas, May 2021).

However, aljournals, several students have started writing book chapters. This kind of publication can be more accessible for students to publish their thoughts because they do not go through a blind review process. The student of International Relations Department UPN, 'Veteran' Yogyakarta, has published several books written by the lecturers. These books include "America in the Middle East," "Tourism Development Strategy," and "Handling the Covid 19 Pandemic in Southeast Asia" (all written in Indonesian).

The third strategy is writing assistance by changing the role of journal reviewers. For this purpose, the editor provides a writing service for each article. Writing assistance is verified so that each writer can improve the quality of their writing, so the article deserves to be published. The writing assistance is in line with what students want to get help in writing, as stated by Saefulloh regarding the writing difficulties he faces, "There is no mentor who can be asked flexibly, friendly and competently". (Online Open Questionnaire, Haris Saefulloh, April 2021).

The strategy seems to provide more hope for the improvement of student scientific writing. When students are given a platform for their writing and receive writing assistance, it appears that their self-confidence is greater. Although not many have submitted draft articles, more tangible results have been obtained through OJS strategies and mentoring. Ten out of twelve articles entered into the OJS system; seven deserve to be upgraded until they deserve publication. From the writing assistance, Syahdani said that his paper improved better than before receiving comments and suggestions from the reviewer. He didn't even imagine that his writing would be so much better than before (Personal Communication, Muwaliha Syahdani, June 2021). The process of writing assistance helped him improve his writing from the perspective used in dissecting the concept of regionalism. As well as Syahdani, Maulana said that he understands better how to present an article coherently and compose an introduction to show problematic issues (Personal Communication, Maulana Ilhami, June 2021).

From the writing assistance practice given to students, the lecturer found many interesting facts 
in scientific writing. First, students have enthusiasm in writing and are very enthusiastic in searching for data. Current information technology support gives writers a great opportunity. It conducts documentary research, primarily when students can access the books in libraries and scientific articles in journals online. Unfortunately, a sufficient understanding of scientific writing has not followed the student's enthusiasm. They haven't the ability to present the writing systematically. The limited knowledge of theories and concepts to explain the issues also prevents them from searching and compiling data according to their needs. Inability in scientific writing is also exacerbated by reading from news portals and public assumptions abundant on the internet. As a result, the assumptions made have absolutely no valid theoretical basis. Second, through a personal approach, students have better motivation to write than in large classes with many students. Limited discussion of written drafts and writing practice is more effective for students to write than explanations and encouragement to write through scientific writing socialization.

The last stage of the action research is evaluation. This evaluation stage examines all the strategies that have been tested to influence student behavior. Of the three methods pursued, socialization and coaching clinic are the first steps to provide knowledge about scientific writing. These two strategies are mandatory because not everyone can quickly understand how to compose articles and the rules of scientific writing. Coaching clinic also needs to be done to encourage the emergence of writing ideas. The writing assistance strategy is the primary key in all activities to increase student scientific publications because from this writing assistance; students receive personal and comfortable writing assistance.

4.1

Conclusion

Scientific publications are one of the main requirements for the accreditation of majors. The Director-General of Higher Education has determined the scientific publication as an academic obligation for students. In addition to scientific publications as a vehicle for various ideas, scientific publications are also a good portfolio for students' academic careers. The low number of scientific publications by students of the Department of International Relations, Yogyakarta 'Veterans' National Development University is certainly not beneficial for the department and the students themselves.

Action research conducted to find obstacles and at the same time look for the best strategy in encouraging the quantity and quality of scientific publications resulted in exciting findings: 1 . The writing problems faced by students are still fundamental in scientific writing, such as finding ideas, choosing the proper concepts/theories, scientific writing rules, and even making sentences and paragraphs, 2. The strategy of socializing scientific writing and writing clinics still needs to be done even though it does not significantly impact, 3. The primary method to improve the quality and quantity of publications is to provide students with a place to publish their writings.

In addition to publishing their papers, student writing can be encouraged by providing writing assistance for students. Writing assistance can help students improve the quality of their writing and foster student enthusiasm for writing. Online journals can help students in addition to being a forum for publishing their papers; online journals can also help students know the management of scientific journals and the rules of scientific writing.

\subsection{Recommendation}

Instead of requiring an understanding of the way/rules of scientific writing, scientific writing also requires a constructive way of thinking and behavior to conduct scientific research from the author. Of course, this way of thinking and behavior cannot be grown quickly. The non-optimal results of the coaching clinic show that students still have writing problems, such as not having ideas and not being confident. For this reason, further research can be directed to more basic research on the habit of writing and thinking scientifically in students at an earlier level. The goal is to find the best strategy so that students at the initial level have the desire and courage to write scientifically. 
The research results can be the basis for the preparation of learning curricula at the elementary or high school level so that students are not only required to learn to memorize and analyze. They can find problems, wrap problems in exciting presentations and propose problem-solving ideas. The learning model in Indonesia, in general, has not touched this method at the lower level. So, when the student arrives at university, they often experience problems in writing and are not confident.

\section{Acknowledgement}

This research was funded by the Institute for Research and Community Service, Yogyakarta 'National' Development University, Indonesia, through the Institutional Research scheme. We are very grateful for the support that has been given.

\section{References}

Ahmed, Ishfaq, Tehmina Fiaz Qazi, Shaista Jabeen. (2011). "Self-Efficacy: The Predictor of Educational Performance among University Students". Information Management and Business Review Vol. 3, No. 2, pp. 57-62, Aug 2011 (ISSN 2220-3796)

Burns, Anne. (2015). "Action Research". In JD. Brown dan C. Coombe. The Cambridge Guide to Research in Language Teaching and Learning. Cambridge: Cambridge University Press.

Cho, K. and Schunn, C.D. (2007). Scaffolded writing and rewriting in the discipline: A web-based reciprocal peer review system. Computers \& Education, 48 (3), 409-426.

Ismail dan Elihami. (2019). "Pelatihan Penyusunan Artikel Publikasi Ilmiah bagi Mahasiswa Perguruan Tinggi STKIP Muhammadiyah Enrekang". Maspul Journal of Community Empowerment (MJCE), E-ISSN 2580-0469 Vol 1 No. 1 (2019). DOI: https://doi.org/10.33487

Hidi, S \& Boscolo, P. 2008. "Motivation and Writing". In Charles MacArthur, Steve Graham, and Jill Fitzgerald (ed.). Handbook Of Writing Research, pp 144-157. New York: The Guilford Press.

ISJD, http://isjd.pdii.lipi.go.id/

Johnson, A. P. (2012). A short guide to action research (4th ed.). New Jersey: Pearson Education

Kartowagiran, Badrun. (2005). Dasar-Dasar Penelitian Tindakan. Universitas Negeri Yogyakarta .

Lodico, M.G., Spaulding, D.T. and Voegtle, K.H. (2006). Methods in Educational Research: From Theory to Practice. San Francisco: John Wiley.

Mahyuddin, Rahil, Habibah Elias, Loh Sau Cheong, Muhd Fauzi Muhamad, Nooreen Noordin \& Maria Chong Abdullah. (2006) ."The Relationship Between Students' Self-Efficacy And Their English Language Achievement". Jurnal Pendidik dan Pendidikan, 21, 61-71.

Maxwell J. (1992). Understanding and Validity in Qualitative Research. Harv Educ Rev. 1992;62(3):279301. doi:10.17763/haer.62.3.8323320856251826.

Pajares, F \& Valiante. (2008). "Self-Efficacy Beliefs And Motivation In Writing Development". In Macarthur,C.A, Graham,S., Fitzgerald,J. (ed.). Handbook Of Writing Research, 158-17o. New York: GuilfordPress

Riduwan. (2015). Skala Pengukuran Variabel-Variabel Penelitian.. Bandung: Alfabeta

Stein, M., Dixon, R. C., \& Isaacson, S. (1994). "Effective Writing Instruction For Diverse Learners". School Psychology Review, 23(3), 392-405.

Sugilar, Hamdan, Tedi Priatna, Wahyudin Darmalaksana. 2019. "Strategi Perguruan Tinggi dalam Meningkatkan Publikasi Hasil Penelitian". Al Fitrah. Vol 7, No 1 (2019).

Supriyanto, A. (2015). Harapan, Kenyataan dan Strategi Peningkatan Kemampuan Guru Dalam Penulisan Karya Tulis Ilmiah. Prosiding Seminar Nasional Pengembangan Keprofesian menuju Guru Profesional di Universitas Negeri Malang.

Troia, G.A. (2003). Effective writing instruction across the grades: What every educational consultant should know. Journal of Educational and Psychological Consultation, 14 (1), 75-89.

Wiley. (n.a.) https://authorservices.wiley.com/Reviewers/journal-reviewers/what-is-peer-review/types-of-peerreview.html

Widyanuratikah, Inas dan Yudha Manggala P Putra. (2019). "Publikasi Ilmiah tak Sebanding Jumlah Dosen dan Mahasiswa”. Republika.co.id. https://www.republika.co.id/berita/q1kggl284/publikasi-ilmiah-tak-sebandingjumlah-dosen-dan-mahasiswa . 